Fecha de recepción: marzo 2020 Fecha de aceptación: abril 2020 Versión final: mayo 2020

\section{Foco en la Experiencia del Cliente. Qué, por qué y cómo de este paradigma estratégico y organizacional, con un epílogo sobre la economía circular}

Leandro A. Viltard ${ }^{(1)}$

\begin{abstract}
Resumen: Bajo la complejidad y las incertidumbres de los mercados reales, como nunca antes, los clientes están interrumpiendo el juego empresarial desde el exterior, transformando la forma en que operan las organizaciones / áreas funcionales y cómo piensan o actúan las personas. Debido a esto, es necesario centrarse en el valor a largo plazo del cliente, los nuevos modelos organizativos, el rol cambiante del Oficial de Negocios / Marketing, las capacidades listas para usar y la integración de tecnologías digitales, para lo cual la Experiencia del Cliente (EC) los niveles de operación deben elevarse en muchas más organizaciones. Como consecuencia, se debe inculcar una perspectiva de link-to-value en la operación de EC en toda la empresa, enfocándose en el model/journey del cliente y en una nueva mentalidad, necesaria para implementar un entorno comercial ecológico.

Se estudia la EC, el valor a largo plazo del cliente y asuntos relacionados, proponiendo ideas para una mejor implementación en empresas de todos los sectores y tamaños industriales. La hipótesis de este trabajo, que se corroboró, sugiere que es posible mejorar los resultados, el rendimiento y la competitividad de la compañía, elevando su nivel de operación EC e implementando un entorno empresarial ecológico. Se utilizó una metodología cualitativa con un estudio bibliográfico, exploratorio y descriptivo, con un diseño no experimental y transversal.
\end{abstract}

Palabras clave: Experiencia del cliente - experiencia de usuario - actuación - competitividad [Resúmenes en inglés y portugués en la página 146]

(1) Doctor en Administración, Contador Público y Administrador de Empresas (Universidad de Buenos Aires, Argentina). Executive Development Program, Northwestern University, Kellogg, Chicago, USA. Veintitres años de experiencia como Associate \& Visiting Professor en diferentes programas nacionales e internacionales. 


\section{Introduction}

Uncertain and complex markets and other factors are changing the business game and many of its functions. In accordance with Day (2016) responsibilities and activities in the marketing arena are having a tremendous impact due to the following three driving forces: digital technologies, the changing role of the Marketing Officer and new organizational designs. These markets impose executives to act as visionaries, build uncontested capabilities and integrate digital technologies for marketing investments' return and sales force alignment. Winning strategies are obtained looking outside and based on having market insights, putting in customers' lens and building a world-class marketing function that can foresee changes and implement the necessary value added actions. In this environment, the author recommends that the Marketing leader must focus on global branding and growth strategies to position the business for the future.

The origin of this huge market disruption is being addressed by different authors. For instance, Teixeira (2019) says that customers -and not technology or start ups- are driving it, and that:

- Successful disruptors better serve emerging customers than larger competitors. Newcomers simply serve emerging customers needs faster in a part of the value chain that was broken and incumbents didn't see them coming. An example is Sephora that disrupted the beauty products arena with the following proposal: a) testing at adequate prices, b) displaying in a different way, c) sample-size face creams, and d) colorful eye shadows. After, in 2010, Birchbox appeared with an innovative idea: pay for a monthly fee and you will receive a box with the better products already identified for you.

- For many and looking at Apple, Facebook, Amazon or Google, disruption is caused by technology; but -in many industries- the disrupter and the disrupted have similar technologies. So, what is changing are customer needs, wants and behaviors.

- Companies are gaining competitive advantages by what the author calls "decoupling": capturing one piece of the customer value chain or by following steps a customer takes to select, buy and consume a product/service. As an example, is cited Trov's app which is an insurance start up that allows making a quick insurance of expensive belongings for a short period of time, a business in which insurance companies are not interested. As a result, it is possible to insure a camera of $\$ 700$ for a week that will take your trip next week, and then cancel it as soon as you come back to your home city.

- To survive to this disruption, incumbents modify their business models, sales channels, and look for new revenue streams and customer segments. Also, they glue back the part of the value chain that was broken.

- It is easier to know what direct competitors are doing than understanding how consumers are disrupting markets all over the world. In this way it is necessary to look at the following seven consumer categories that represent 90 to $97 \%$ of spending and suggest early signs of behavior change: 1) where they live, 2) what they eat, 3) what they wear, 4) how they move, 5) how they heal, 6) how they educate, and 7) how they entertain. A change in consumer behavior impacts on one of these seven industries. 
- Nowadays competition is against thousands of start ups in any market that -with fewer resources- can compete with big firms. Also, that business models must evolve as consumers -and not startups or technologies- are disrupting markets.

- Recommends three layers from which entrepreneurs or executives embraces customers' vantages, and can create successful startups: 1) articulate the current/standard business model taking the current reality as foundation as customers evaluate the startup with what they already have; 2) develop a digital equivalent of the current/standard model. As an example, TaskRabbit represents the digital equivalent to hiring for household chores like housekeepers and gardeners, and 3) determine how to innovate on top of digital business models, benefiting users but creating downsides, too. In this sense, TaskRabbit accelerates the process of selecting people for household chores but requires that you allow strangers inside your home.

- Smart entrepreneurs try to transcend digitalization, producing customer benefits. Tas$\mathrm{kRabbit}$ personally assigns butlers as a more trustworthy and reliable service.

- These three layers help to understand stakeholders the incremental value proposed by a new business idea in comparison to the traditional approach.

Going deeper, specialists like Simons (2014) put their focus on the primary customer identification and on the whole value chain in order to improve the value proposition and the business model. Reflects on what a customer should be considered as -in some firmsit is not so obvious, for which the most important customers may actually supply little or no revenue. Also, states that:

- Identifying a primary customer helps to get aside from competition. For most of the firms, it is an entity or a person who buys its products/services, but for others -like Merck, the pharma giant- they are the scientists in labs and universities around the world. As a consequence, they encourage their own world-class scientists to conduct basic research, publish papers and present them in conferences in order to discover ground-breaking compounds that could be transformed into products/services. As a result, the business is configured like a research university with a centralized R\&D function.

- A narrow customer understanding and defining all the value chain as customers can be a strong particularity in uncertain and evolving markets, for which it must be improved the internal coordination and responsiveness.

- Comparing Yahoo -a broad Internet base with finance, news, sports and movies- with Google -focused on users that appreciate technology and new applications-, it is seen that companies like Merck and Google allocate their resources to a specific set of customers with a clear value proposition and business model. From this perspective, the primary customer defines the business.

- Amazon is another case, as they serve four kinds of groups: consumers, sellers, companies and content providers, but their primary customer are consumers as it is stated in their mission: "to be the world's most consumer-centric company". As an example and searching for an unparallel customer loyalty and profits, they show their customers a low-price list from off-site competitors, not taking into consideration what other Amazon's constituents say. 
As a consequence, there is a direct and positive relationship between favorable company results and a deep customer understanding/focus, being relevant and urgent to approach this matter which is studied in this investigation. That is why this research aims to deepening on $\mathrm{CE} /$ journey operation, customer long-term value and related subjects, contributing to a better understanding on the matter in order to enhance company results, performance and competitiveness.

The following questions guided this investigation:

- What is the state of the art on CE and how to jump from user to CE?

- What the customer values and what are the basis for customer long-term value?

- Is there a way to raise the $\mathrm{CE}$ operation level?

- Are there any considerations that should be taken into account on CE programs, and CE link-to-value, strategy and innovation?

\subsection{Hypothesis}

It is possible to enhance company results, performance and competitiveness raising their $\mathrm{CE}$ operation level, and implementing an eco-friendly business environment.

\subsection{General Objective}

To study CE, customer long-term value and related matters, proposing ideas for a better implementation in firms of every industrial sector and size in order to improve results, performance and competitiveness.

\subsection{Design methodology and analysis}

It was utilized a qualitative methodology, with a descriptive exploratory study and a nonexperimental design (within them, transversal, since the information was collected at a given moment of time).

The analysis unit refers to $\mathrm{CE}$, customer long-term value and related matters in different kinds of companies.

This is a bibliographical investigation taking into account important world-wide authors and sources. As a result, it does not include a field work.

This research took place in the period September 2019-February 2020, in Buenos Aires, Argentina. 


\subsection{Research limitations/clarifications}

Within the scope of this investigation, were found some limitations/clarifications that are detailed below:

- Although it is difficult to ascertain that all relevant information has been included, the investigation referrers to studies obtained from significant secondary sources.

- The support of this work is referred to literature connected to $\mathrm{CE}$, long-term value and related matters, applicable to every organization, regardless of the particular sector in which it operates or size.

- The present study is complex and multidimensional due to its highly social content. As a result, what is proposed is shown with an open mind and in a professional discussion tone. - The conclusion is supported on the elements that have been analyzed and that are part of the present study.

- Based on the understanding that the study has been qualitative, it is not possible to generalize its findings, although intends to contribute to the decision-making process regarding the studied topic.

The limitations/clarifications detailed above have not been an obstacle to reaching reasonable conclusions regarding the objectives and hypothesis of the present study. Finally, it is indicated that the hypothesis was corroborated and the objective verified.

\subsection{Main Findings}

As a general conclusion of the research process carried out, it is considered that companies $\mathrm{CE}$ operation/journey and long-term value alternatives can help in reaching higher results, and performance and competitiveness enhancements. Digital technologies, out-of-the-box capabilities, the changing role of Marketing/business functions and novel organizational designs are changing the business landscape and executives' perspectives. Changes are coming from the outside of the organizations, and -specifically-from customers, who face every-day life inconveniences that must be resolved disrupting traditional markets with constant-changing needs, wants and behaviors.

Moreover, disruptors are serving better and faster emerging customers, not incumbents anymore, as they break and capture part of the value chain with fewer resources. Business models, value chains, resources allocation and the whole businesses are being impacted by business/processes innovations to better serve primary customers -which not necessarily are the ones who pay the product/service- with unimaginable value propositions and more benefits.

Company results are connected with a better understanding and focus on customers, obliging firms to put $\mathrm{CE}$ at the center of their strategies and actions. Company executives 
must excel on four types of elements that are valued by customers: functional, emotional, life changing and social impact/self-transcendence elements; the latter, restricted to a few brands that help people to feel better and realized in their lives.

It is required a value mentality and link-to-value perspective; new business models and value propositions on CE programs; and -also- investments in algorithms and machine learning advances in order to jump from user to $\mathrm{CE}$, which needs a human touch. Revisiting CE operations or introducing deep cultural changes are what business executives must do; for that, focusing on the customer model/journey and training/education on service excellence become imperative.

Executives of modern organizations are required to have a deeper customer focus and understanding, and make better CE programs' implementation, based on new requirements of the digital age, and on processes that take care of the planet and are customer friendly. A new mindset is needed to implement an eco-friendly business environment with circular economy business models.

\subsection{Originality and value}

This study intends to give an overall perspective on CE operation and its connection with the circular economy, although there are partial studies on the matter. Its adequate understanding and implementation can contribute to higher levels of company results, performance and competitiveness in the business arena.

Implications to this paper can refer to a wide basis, from the micro level -when executives focus on daily decisions- to the macro level, when government or non-government organizations prepare plans to support these firms.

\section{Theoretical background}

The following paragraphs show the theoretical background that supports this study, which includes what a customer values and how to instill the basis for customers' long-term value; the understanding of Customer Experience (CE) and its importance; and -finally- a perspective on CE programs, link-to-value and strategy.

What a customer values?

Understanding what a customer values is not only connected with price, but also with psychological matters. Almquist, Senior \& Bloch (2016) assert that opportunities -in existing or new markets- are based on universal building blocks of value that consumers recognize, and that the easiest part of the marketing task is to focus on prices -as rising them can boost profits- but the hardest is to go deeper on what a customer values, as it is connected with psychological matters.

They identified 30 elements of value which are connected with Maslow's hierarchy of needs and focus on consumer behaviors around products/services. It is proposed a pyramid with four categories that are described from bottom to top needs, as follows: 1) functional 
(ex.: saving time, reducing costs, quality), 2) emotional (ex.: reducing anxiety, providing entertainment), 3) life changing (ex.: provides hope, motivation) and 4) social impact, at the peak (self-transcendence). Sometimes an emotional benefit (reducing anxiety, for instance) can be as important as a functional one (save time). These 30 elements of value, if optimally combined, can increase customer loyalty, brand awareness and revenue growth. That is why companies should establish a discipline on the following three areas: new product development, pricing and customer segmentation.

Some of the results of their studies are summarized as followed:

- Companies that performed well on multiple elements of value would have more loyal customers than others, being impossible to score high on the 30 of them. The best was Apple Inc., scoring very well in 11 elements. It is imperative that firms must choose strategically those elements.

- Strong performance on multiple elements -four or more- correlated with faster revenue and market share growth in comparison with others. Amazon achieved a high score on 8 elements, showing the power of adding value to a core offering. Then created Amazon Prime, selecting some product features, which now includes streaming media, unlimited photo storage on Amazon servers, and others that enlarged their offering and helped them to be apart from a commodity status.

- Some elements did matter more than others. Quality appeared in every industry, but in some of them the various elements were different. For instance, in food and beverage it was important "sensory appeal", while in consumer banking were significant "access and good investment for future generations".

- Consumers feel that digital firms offered most value as they save time and avoid hassles. Zappos rated very well on 8 elements, far more than traditional retailers, and Netflix rated three times better than traditional TV service providers.

- Brick-and-mortar businesses could still win on certain elements. As an example, omnichannel retailers won on emotional and life-changing elements when consumers were helped by employees in stores. Physical businesses were being transformed, and not annihilated by technology; its fusion with digital channels provided more power than each one alone. In this way, Amazon expanded functional excellence in a mass market and Apple charges high premium prices excelling on 11 elements of value.

- Firms must excel on the elements that are part of their core values, adding others that may expand their value proposition and respond to customers' needs better than competition.

- The hunt of value mentality should be instill in every organization and every employee, and should be part of the innovation process. As a result, firms should:

a. Identify which elements are the most important for their industry. For instance, in the apparel retail it was appreciated quality, variety, avoids hassles, design and saves time; and in consumer banking the most required were quality, provides access, avoids hassles and reduces anxiety.

b. Improve crucial elements. 
c. Deliver new elements through product designs areas, although it may be not so obvious which one to add.

- To implement this model the customer should be listened and put at the center of design concepts. With this in mind, the following aspects must be taken into consideration: a) stimulate ideas for new products/services and new connections with consumers, b) discussions on raising prices should consider the addition of value elements, and c) emphasize customer segmentation on demographic or behavioral groups, and follow the one that may bring most opportunities.

- These elements can add brand and product/service value, gaining an edge with consumers, who are the only ones that recognize and pay for value.

The following Table summarizes what it was said in this section:

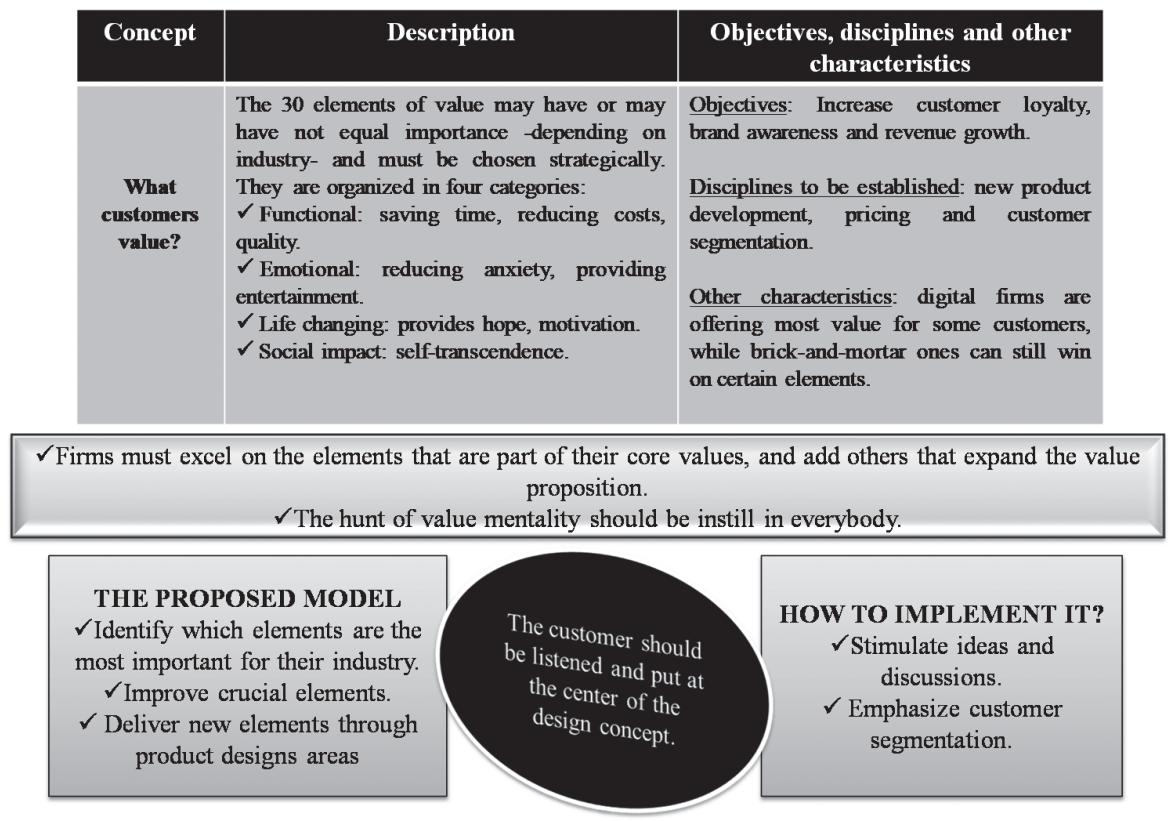

Table 1. - What a customer values?. Source: Own 
Instilling the basis for customers' long-term value.

Marketing strategy and ROI (Return On Investment) are connected with creating a longterm value proposition. That is the reason why Senz (2019) asserts that -from the first purchase- companies should identify shoppers that will create long-term value, being important the following matters:

- The information collected in the first customer's purchase, as it will serve as a marketing tool -leveraged by machine learning technology- to predict future customer's behavior. Firms must improve the use of most of the collected customer data, especially in new customers where no historical data exists.

- Improve marketing strategy and ROI through algorithms that can predict which customers will repeat purchases, and which will be the best email campaigns.

Complementing what Senz says, Ascarza \& Padilla (2019) suggests that it is possible to identify which customers can be future heavy spenders and the ones that will be most responsive to future email promotions through an algorithm that creates a first customer impression by interpreting certain cues and traits.

They analyzed a sample of 13,000 customers -of six different markets- for a beauty products' brand, considering the following six variables: 1) online/offline purchase, 2) number of items purchased, 3) if the items purchased were newly released, 4) prices, 5) discounts, and 6) if the purchase was made on holidays. Results showed that:

- Customers who bought more products in a first transaction, especially in stores, had more chances to repeat their purchases in the future, and that the ones that bought newly released products are potential high-value customers. Contrasting with this outcomes, the ones that bought discounted products, specifically those in Black Friday or during holidays, were lower-value and often one-time customers.

- In different industries -like retail and charitable organizations- and with the help of data scientists and clean historical customer data, it was possible to predict purchasing motivations; so it must be determined which variables should be followed and managed with machine learning advances.

- Companies should invest more in algorithmic tools in order increase business/customer understanding and help decision making. Obtaining richer data from the first transaction (coinciding with Senz, 2019) and more precise models can develop an unseen business and marketing potential in the future.

In the following Table, it is shown a summary of what was said in this section: 


\section{Identify shoppers that will create long-term value, being} important:

- The information collected in the first customer's purchase.

- Investments in algorithms and machine learning advances which should improve marketing strategy and ROI, identifying heavy spenders, high- value customers and purchasing motivations.

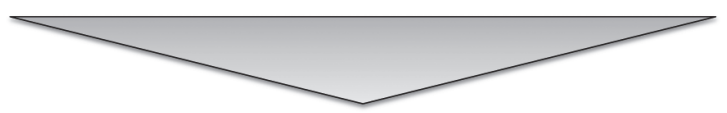

Objectives

Obtain richer data from the first transaction. $\checkmark$ Implement more precise models.

Final goal

Develop an unseen business and marketing potential in the future.

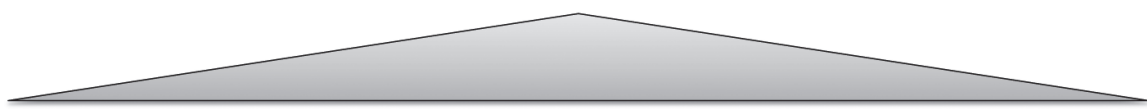

Table 2 - The basis for customer's long-term value. Source: Own

\section{Understanding Customer Experience (CE): its importance and challenges}

Focused on every customer interaction, CE is an evolving concept with the absolute goal put on customer loyalty. Silverthorne (2019) says that more and more firms are competing on CE basis; though providing great customer service -called today CE- becomes the responsibility of the whole company, not only of one department. Also, it is indicated that expectations must be exceeded, implying to go against what Theodore Levitt understood as marketing myopia: adopting an insular marketing approach where business needs are ahead of the customer. The author indicates that this thinking evolved in the last decade to a CE concept, understood as the ability to capture customer loyalty by constantly delighting consumers in every interaction.

As a result, it is imperative that firms deliver a great and distinctive CE. In this sense, Richardson (2015) says that it means to focus on organizational capabilities in order to integrate individual customer interactions, and to instill an organizational mindset on their needs. Also, makes a distinction between user experience -to create great looking products and easy to use- and CE, which delight customers and expands business over time.

In accordance with the author, user experience is first and it is connected with product design and the interactions that occur on it. But, CE appears afterwards stitching all together with many other touchpoints (front-line staff, promotional emails, and store environment, among others). 
Additionally, says that it is necessary to iterate user experience, improving usefulness and usability, and integrating $\mathrm{CE}$ across touchpoints. To carry out all this matters and improve the experience, customer feedback becomes important. A case of what it was said is Google Maps updates (zoom or better traffic instructions) and the feature that marks traffic heaviness with red, yellow and green lines.

Finally, the author gives some recommendations to make a jump from user to CE, as follows: a) integrate across touchpoints: make each one act as a ramp to another, b) don't ignore the plumbing: a boring infrastructure can be found behind the scenes of each touchpoint but what the customer does is to interact in a simple and easy way to achieve the desired results, c) make the experience personal: acknowledge the individual customer's situation and demonstrate that you understand their needs, and d) make feedback part of the CE: to see if you are moving in the right direction.

But, the environment in which firms operate and the technology that is used play a key role when managing customers. Shell \& Buell (2019) suggest that firms manage stressful customer interfaces with Self-Service Technologies (SSTs) and that there are companies that operate in high-anxiety environments like financial services, health care, and education. For instance, patients may be asked to use kiosks to check themselves into hospitals, although customer anxiety when using SSTs can reduce their trust in the service provider. Anxiety has a negative effect on customer satisfaction, trust, and long-term engagement. So, operational design choices -as availability or access to human contact and/or experts- can be applicable in these cases.

In this context, improving CE becomes core. That is the reason why Richardson (2010) suggests that customer journey maps -understood as the steps that a customer goes in order to engage with the company through a product, service, experience or a combination of them- can help to improve CE, adding that:

- These maps become useful when many touchpoints make a connection between the firm and the customer, or when it is necessary to look at specific company interactions.

- A journey should be treated like a storyboard, with photos and sketches of each stage. It is not a single way to create it, but it begins with the first customer contact and can end in different ways: with a product/service upgrade, a replacement or by choosing a competitor's offering. But, this journey may not be linear: a customer may jump from awareness to purchase if he/she has a strong recommendation from a friend to buy or if he/she is not inclined to do research.

- Complexity and jargon must be avoided when contacting customers to improve their product/service experience.

- Basically, the sales funnel is composed by awareness, research and purchase, but ultimately OOBE (Out-Of-the Box Experience) has become a very important step, too. In this way, a good experience minimizes expensive calls and contributes to a good business sense, more than only call for emotional factors.

- In constructing a customer journey map it should be looked at the following areas: a) Activities: actions that the customer does at each stage, b) Motivations: why he/she should go to the next stage and the emotions that is having? c) Questions: uncertainties, jargon 
or other issues that prevent him/her to move to the next step, and d) Barriers: structure, process, cost, implementation or other matters that may prevent him/her from moving to the next step.

- Customer research must be conducted through ethnographic interviews and in-context observations, surveys and focus groups.

As a result and in the following Table, it is shown a summary of what it was said in this section:
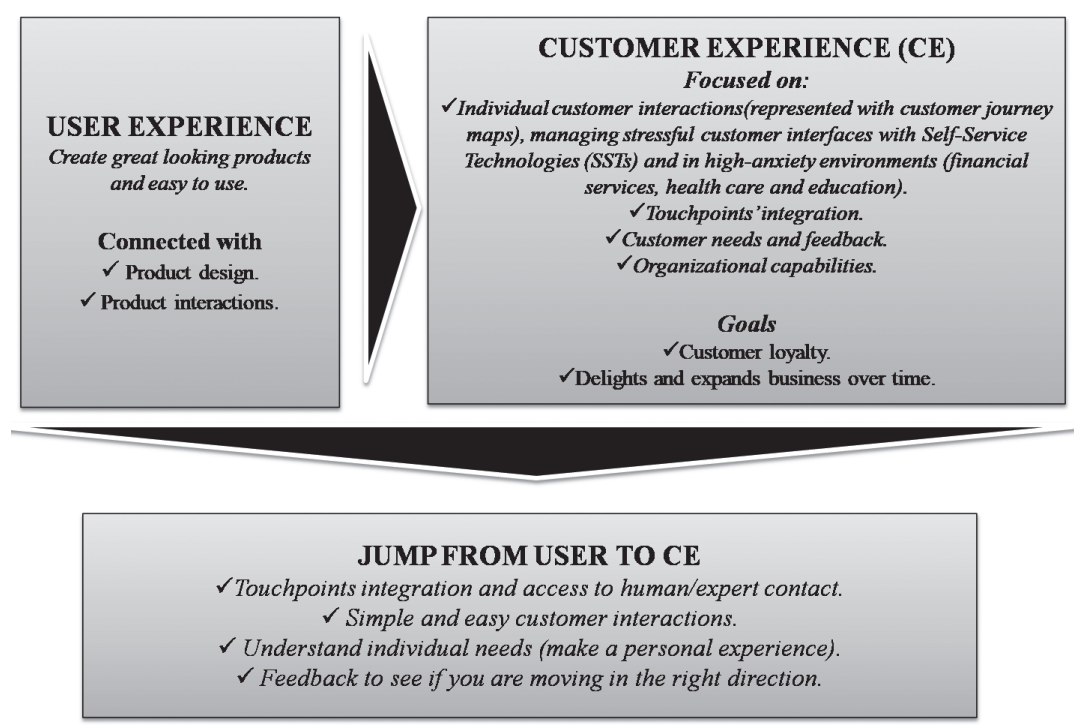

Table 3 - From User to Customer Experience (CE). Source: Own

As a consequence, jumping from user to $\mathrm{CE}$ has become one of the biggest challenges that firm's executives are facing, for which it must be raised the level of customer service. In this sense, Wirtz \& Kaufman (2016) suggest that:

- In firms where service operation is working reasonably well, it is necessary to introduce incremental improvement practices through revisiting what frontline employees do and conducting pilot projects. But, when the industry has a disruption and/or the operation is badly broken a deep cultural change should be applied.

- Social media is giving unhappy customers a louder voice, so customer interactions are becoming increasingly important and service a never-ending goal in which people must be put at the center of every strategy and action. 
- The following four practices -alone or in combination- may work well in global customer service operations, helping to differentiate on service and producing rapid and sustainable success:

1. Be sure that front desk employees have an adequate support -like logistic, IT and backend supporting functions-, but don't start with them. At this stage, the main focus refers to instill an adequate training on customer responsiveness.

2. Educate people on service excellence, not focusing on specific skills or scripts in order to make them more imaginative or empathetic about customer's needs. The objective is to create value for others, understanding and responding to their concerns. Service, needs and value are keywords in this matter.

3. Go company-wide and don't pilot limited experiments as -for deeper changes- firms must create momentum fast and set high goals.

4. Metrics and tracking should be on value-adding actions implemented and not on the traditional ones such as share of wallet and NPS ${ }^{1}$. Easy and simple questionnaires -instead of quantitative ones- are better to understand what makes customers happier in future interactions instead of only his/her satisfaction with what was received.

Out of what was said, the following Table shows a summary of elements needed to raise customer service possibilities:

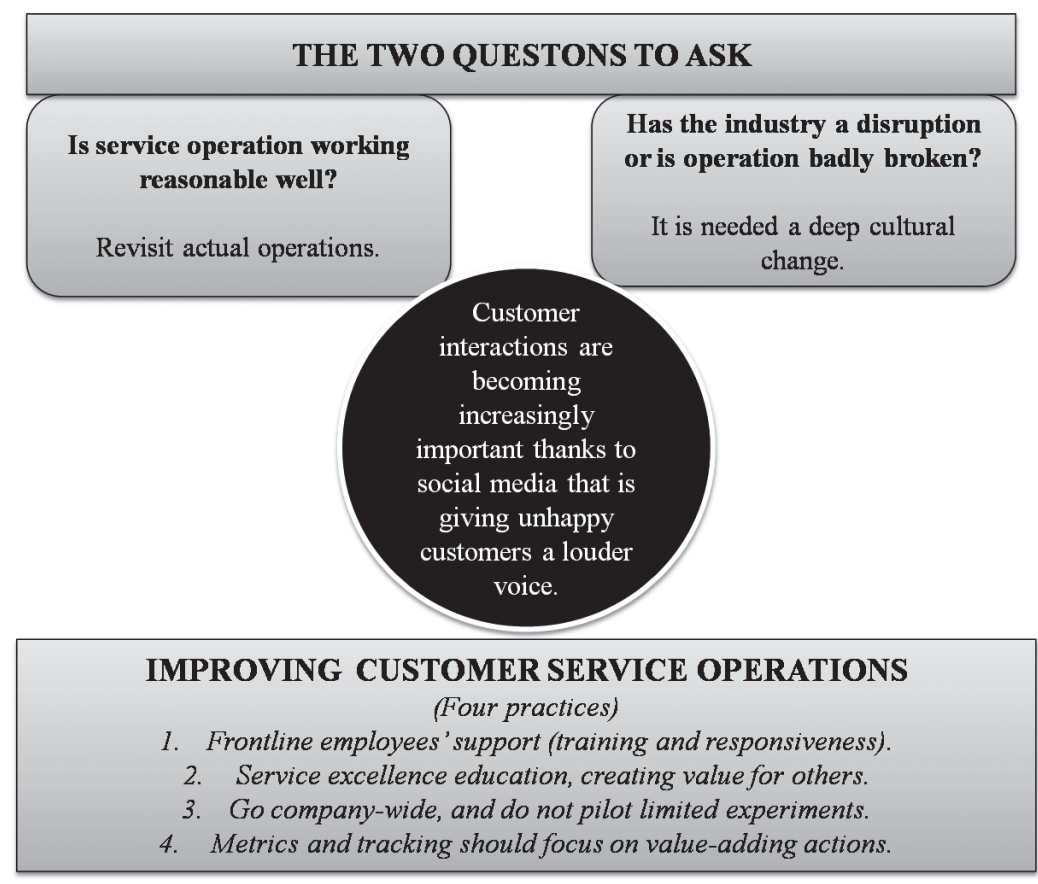

Table 4 - Raising the customer service operations level. Source: Own 


\section{Customer Experience (CE): programs, link-to-value, strategy and innovation}

One of the main concepts said up to this point, refer to the importance of CE programs, a central issue in modern firms. Maynes \& Rawson (2016) recognize that there are many good intentions in CE programs but not so many results as it is difficult to quantify the economic outcomes of differences in CE. A link-to-value perspective and a self-funding business case are a must when speaking about this kind of transformations.

The authors say that a link-to-value perspective requires a structural approach, covering:

- What is important to customers: based on: a) behaviors; b) expected value outcomes for your industry; and c) their satisfaction and loyalty, both linked to business results. As an example, it is cited the case of airlines that should focus their actions on capturing a greater share of trips, higher revenues and lower costs. So, what becomes important is to: 1) identify the three to five key outcomes that will be translated into delivered value measures, 2) link customer satisfaction to their behavior over time, 3) analyze historical performance of different customer groups -like satisfied, neutral and dissatisfied- to understand how much less subject to churn are they and in which ones to invest, and 4) track the outcomes of each customer segment that matters, setting priorities to improve customer experience and business outcomes.

- Focus on the customer model, keeping a high CE: investments must be directed to where they will have most impact and do most good; that is customer satisfaction issues with the highest payouts, being necessary to reduce detractors or create more promoters. But, CE break points are not standard in every industry. For instance, in the health industry it is better to improve the dissatisfy customers' experience becoming them passive, than to turn the passive into the category that will promote new services. On the contrary, in retail banking every promoter does matter. As a consequence, it should be built a model based on the whole customer journey performance -with a long-term costs and revenues perspective-, not on an individual touchpoint. It should start from rethinking the scope of the existing surveys, covering the key elements of the customer journey and less of his/ her satisfaction, based on advanced analytics. Another important issue is to identify if performance is consistent as sometimes a low customers' percentage have a perfect journey. It means that customers shouldn't have extra sales/support calls, zero callbacks, quick service activation, and good service experience in the first days, with no issues on the first invoice. After, an always-improvement mind should be put in place -taking the customer and employee voices in consideration- to focus on where performance may be improved, and -also- identifying expectations and opportunities. Visits, focus groups and interviews may constitute adequate tools to understand the customer journey and pain points, that should be sized based on their possibility of cost reduction, long-term revenues and loyalty. Finally, it is important to differentiate the firm from competitors, being fundamental to identify opportunities for innovations and disruption in white spaces. For instance, digitalization, branchless and paperless experiences are increasingly requested from retailbanking customers, so improving the branch experience becomes less worth. 
From the above, it appears that the customer constitutes a central point in the firms' businesses, being important that every company strategy and action advance his/her needs, tastes and behaviors. Replying to this precept, Simons (2014) proposes a four steps customer-driven strategy that is explained in the following paragraphs:

1. Identify the primary customer, meaning a customer group that best fits the company culture, history and capabilities, and offers profit potential.

It must be understood that the most important customer is not the one that is producing more revenue, but who can unlock most business value. To choose him/her in the right way it should be considered the following aspects: a) perspective: mission, culture and folklore of a business, b) capabilities: resources embedded in a firm that are difficult to copy and are directed to a specific set of customers (ex.: technology, brand marketing or logistics, among others). Dell Inc. originally focused on the final consumer with a low-cost logistics operation, although now they are refocusing on CIOs of large companies, which is a difficult path because CIOs are looking for a group of capabilities (integrated HW, sw and/or solutions in services) very different than an end consumer, and c) profit potential: customer's abilities to deliver profits. For instance, Porter's five competitive forces can provide a profitability analysis by customer type, helping to make better choices on whom to serve. An example of this case is Wal Mart that is focused on cost conscious customers, delivering high profits through volume. Linkedin is another case, focusing on individuals, not on advertisers or recruiters.

2. Understand what your primary customer values, based on primary customer's behaviors, habits and values, and on tracking preferences and purchases.

Different things may be demanded by different customers within the same industry and market, and sometimes they don't know what they value. Low cost, dedicated services, and best brand or technology are only some examples. Today, firms like Nestlé evaluate -in real time and through analytics- how well their value propositions are meeting what primary customers want. Other companies, like Fedex, establish systematic dialogues with customers asking if they are feeling good with the services they receive. Firms with rapid product cycles, like Google Gmail, establish their dialogue through new-product testing and interrelations with opinion leaders.

Moreover, ethnographic methods are used in firms when they want to launch products that are not already known by consumers. $P \& G$ sends many specialists to the field to share a family dinner table or a shopping trip in order to understand to what extent products meet consumer needs. As an example, it is mentioned that Downy Single Rinse, a fabric softener that is best used for countries like México where water is in short supply.

As a result, it is recommended to set up a process to assure that products and services meet customer needs.

3. 3Allocate resources to win, implementing the best business model that fits customer needs and preferences.

The author identifies five different business models to adopt, depending on what is important for the primary customer: 1) low price: allocating fewer resources to customer- 
facing units like Wal Mart, 2) local value creation: pushing resources out to regions, customizing products and operating the less core functions as possible centrally, 3) global standard of excellence through best brand or technology: organizing resources globally, and focusing on R\&D, distribution and brand marketing. As an example, Microsoft has separated business units -with full revenue and profit responsibilities- for Windows, servers, MSN mobile, and Xbox, 4) dedicated service relationship: approaching customers that look for an ongoing and embedded way of working. IBM is organized in industrybased customer teams in order to fulfill the different customers' requirements and 5) expert technical knowledge: sitting R\&D on top of product organizations and making the other functions play a supporting role. In this case, an additional focal point should be put on product development and breakthrough technology with stand-alone sales functions as separate units.

Different configurations and permutations of these five basic business models may be found across sectors and organizations, but -as a general rule- when a firm has more than one primary customer it should be split into different units with the configuration -for each of them- that best serve their needs. Nestlé has a general model of local value configuration, but for brands as Nespresso and Mövenpick they use global standard of excellence as customers want a premium and consistent experience regardless of location. Though, in these two cases resources are managed centralized and globally.

At the end, the management options must reflect the primary customer choices.

4. Make the control process interactive, adopting an adequate system that respond to changes in needs.

Threats and opportunities are always refining customer values and their profit potential. New behaviors, tastes, choices, demographics, regulations, competitors and technologies conspire against business models, changing the competitive environment. Dramatic changes must reorient business models and it is worst if these factors impact on the primary customer. So, in radical situations a new primary customer should be selected through an interactive and centralized control system that provides the best information for decision making.

Tracking company success depends on the emphasis that companies' executives want to give to diverse factors like profits, branding and orders, among others. In HBO, for example, management center its attention in bidding for new shows from filmmakers and Amazon's Monday meetings on product assortment, revenue growth, customer orders, and inventory turnover. In these companies, managers interpret data and come up with actions plans that may contribute to novel strategies. But, uncertain markets require the best information -shared at all organization's levels- to produce applicable and updated action plans through interactive control processes.

The author concludes that a company cannot be everything to everyone ${ }^{2}$ like Yahoo, recommending selecting a business model strategy that best suits the primary customer. 
As it was said, customers are a central point in every firm's strategy and implementation, being fundamental to take every opportunity to innovate. Taking this into consideration, Maynes \& Rawson (2016) reaffirm that these opportunities can be achieved if:

a. A voice-of-customer/CE analysis is performed as a starting point, and -then- operational data is considered for digital-innovation alternatives. For example, multiple calls to obtain a new car loan could be transformed in an online digital-loan solution, reducing the cost to serve and promoting loyalty.

b. An ethnographic research is conducted, going deeper in customers' daily lives, and identifying unmet needs and new ideas that could be transformed into products/services.

After analyzing what matters to customers, setting priorities and weighting the fundamental initiatives, the authors suggest constructing a road map, supported by a long-term business case. Also, it should be calculated each initiative's expected value, time to capture and cost to implement, balancing the ones that should make a quick pay-off on the largest number of customers.

Finally, they suggest some design principles to build a self-funding and rewarding business case to anchor a CE program, considering the following main aspects: a) ensure quick wins early, b) tackle at least one sacred cow early to show that you are serious (for instance, a pricing or policy element), c) make sure that this road map will touch every employee and customer in the first year and d) use early wins to finance long-term solutions. A summary of what was analyzed in this section is shown in the following Table:

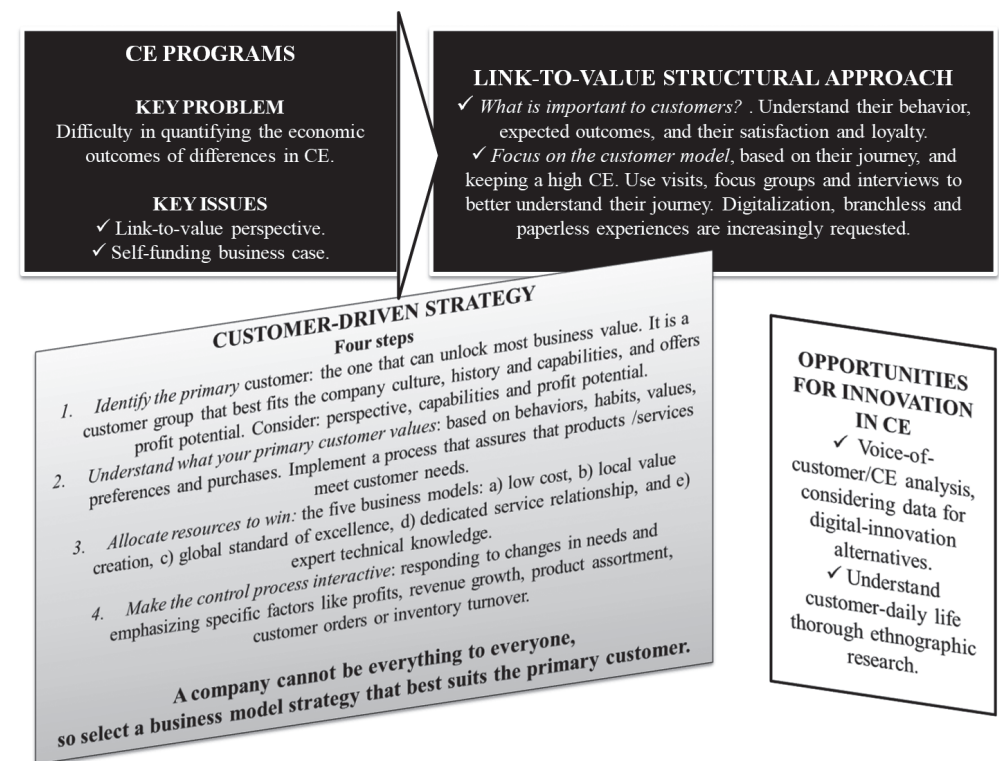

Table 5 - CE: programs, link-to-value, strategy and innovation. Source: Own 


\section{Conclusion}

Under the complexity and uncertainties of actual markets and other driving forces, and as never before, customers are disrupting the business game, transforming the way organizations/functional areas operate, and how people think and act. Because of this, it is necessary to focus on customer' long-term value, new organizational models, changing role of the Business/Marketing Officer, out-of-the-box capabilities, and digital technologies integration for which Customer Experience $(\mathrm{CE})$ operation levels are required to be raised in many more organizations. As a consequence, a link-to-value perspective on CE operation must be instilled at company-wide, focusing on the customer model/journey and on digitalization, branchless and paperless experiences.

Executives must act as visionaries, build out-of-the-box capabilities and integrate digital technologies in order to impact in their markets and set aside of competition. More than ever, changes come from the outside and looking how customers live and the inconveniences that they face everyday. As a result, global branding, growth strategies and value added initiatives are the core of the businesses today.

The center of attention must be put on customers and not on competitors anymore, an old and easy game because customers -and not necessary technology or start ups- are driving disruption; their needs, wants and behaviors are constantly changing.

Also, emerging customers are better and faster served by disruptors, more than large competitors, because they are breaking and capturing a part of the value chain, with the advantage of needing fewer resources to compete. In this context, incumbents must modify their business models, sales channels, and look for novel customers and revenue streams through digitalization and business/process innovation. Value added propositions are constantly evolving in order to produce more benefits to customers.

With the objective of improving value propositions and business models, it is imperative to identify who the primary customer is and the whole value chain. For companies like Merck, the primary customer may be labs and universities -not necessarily the one who pays for a product- that will help to discover compounds which will be transformed into ground-breaking products/services. In addition, in firms like Google, Amazon and Merck the allocation of resources and -finally- the business is defined by the primary customer. Consequently, it is verified a direct connection between favorable company results, and a deep customer focus and understanding. In this sense, organizations must excel on CE, a central strategic issue for every executive.

It is observed that customers value a pyramidal and vast array of functional, emotional, life changing and social impact (self-transcendence) elements that constitute an enormous challenge for firm's executives. But, self-transcendence -the one at the top of the pyramidis restricted to a few brands in their markets, helping people to feel better and realized in their lives.

In this environment, executives are required to:

- Instill a value mentality to everybody and match core values with the mentioned elements, adding others that may expand the value proposition. 
- Unlock business potential and refine business models for the future, beginning with richer data just from the first customer transaction.

- Increase investments in algorithms and machine learning advances to improve ROI and marketing strategy.

- Jump from user to CE, integrating touchpoints with: a) simple and easy interventions, and more human/experts interactions, b) personal experiences built within the customer journey, and c) adequate customer feedback received and processed.

- Depending on each company situation, revisit the actual way of working and/or implement deep cultural changes in order to excel on CE operations. To achieve this objective it necessary that: a) frontline employees have appropriate training and responsiveness, b) service excellence education must create value for others, c) the company should be taken as a whole, not running pilot limited tests, and d) tracking and metrics should measure value-adding initiatives.

As a final conclusion, a link-to-value perspective on CE operation must be instilled at company-wide, focusing on the customer model/journey and on digitalization, branchless and paperless experiences. A self-funding business case should support and be the base for opportunities on CE innovation, through a deeper customer-daily life understanding. In an uncertain and complex world, and more than ever, entrepreneurs, executives and government officials must put the customer at the center of their strategies and initiatives; the customer is forcing to do it !.

\section{Epilogue in the circular economy}

Along this study, it is said that transformation becomes a requisite of a complex and uncertain business world, which must enhance company results, performance and competitiveness. This transformation should cover every organizational stakeholder, from the primary customer to the whole value chain.

In this sense, different authors studied business models transformations and their relation with technology. For instance, Dias et al. (2017) suggest that, in order to produce the required business transformation, next-generation operating models are to be developed, providing speed, precision and flexibility to unlock new sources of value and reduce costs. They propose four building blocks, and one of them is referred to flexible and modular architecture, infrastructure, and software delivery, being technology a core element of these models. Customer journeys can be enhanced with modular architecture supported by flexible and reusable technologies, hanged at the cloud, and enabling businesses to consort with suppliers and partners. Also, they say that software testing, security, delivery processes, and infrastructure changes are being automated.

To achieve this high objective it is required to raise organizations' CE operation level, and -specifically- digital technologies should help when thinking on strategies/actions on $\mathrm{CE}$ and long-term customer value. In fact, it is referred that one of the main focus is connected with the customer model/journey, and with digitalization, branchless and paperless experiences, elements that are in direct connection with the circular economy. 
Going deeper and complementing what was said, this novel model -called circular economy- is studied by different authors. As an example, Antikainen et al. (2018) point out that non-renewable resources are being overused, exceeding the environmental planet capacity and that consumption is constantly growing. As a consequence, a more sustainable and preserving model (circular economy) must replace the current linear economic one. It eliminates waste and the continual use of resources, aiming to keep products, equipment and infrastructure in use for longer; so improving these resources' productivity. Also, it is a regenerative approach, contrasting with the traditional linear economy, which has a "take, make, dispose" model of production. For proponents of these business models, it is possible to achieve a sustainable world not dropping in the quality of life for consumers, with profitability for manufacturers and similar products/services.

To carry out this objective, it is necessary:

- To redesign business models and value chains.

- That the organizations should not sell products, but to retain ownership, and sell their use as a service. Buying and owning products is part of the past as services create value in a different way. As an example, it is analyzed the rental service of a: 1) sofa, which produced personal benefits to consumers and a connection with psychological sacrifices, 2) a washing machine, which benefits were only related to practical matters, and 3) clothing, connected only with psychological considerations.

- That the customers consider the balance between renting and owning, which depends on the economic benefits and sacrifices of each product/service. When buying is economically favorable, it easily wins over renting. Additionally and for some products, personal and emotional benefits are more important than other factors.

As it was suggested in this investigation, a deeper customer focus and understanding becomes a must in modern organizations. In addition and to make an adequate implementation of CE programs, the digital age requires novel infrastructures, technologies, and processes that take care of the planet and are customer friendly. A new mindset is needed to implement an eco-friendly business environment.

As a result of this work, it is concluded that the general objective was verified and the hypothesis corroborated.

\section{Notes:}

1. NPS, Net Promoter Score: is a tool that measures customer loyalty, based on their recommendations. It is based on only one question that customers should respond: how probable is that you will recommend the product/service to a family member or friend.

2. This is one of the 22 Immutable laws of marketing addressed by Al Ries \& Jack Trout. For further information see: Ries, A. Trout, J. (2009) The 22 Immutable Laws of Marketing, Violate them at your own risk, Collins Business-HarperCollins Publishers, USA: New York. 


\section{References}

Almquist, E., Senior, J. \& Bloch, N. (08/31/2016) The elements of value. Measuring -and delivering- what consumers really want, Harvard Business Review, Boston: USA.

Antikainen, M., Lammi, M. \& Hakanen, T. (September, 2018) Consumer service innovation in a circular economy-the customer value perspective, retrieved from https://www. researchgate.net/publication/327719504_Consumer_service_innovation_in_a_circular_economy-the_customer_value_perspective, on 02/09/2020.

Ascarza, E. \& Padilla, N. (Feb., 2019) The value of first impressions. Leveraging acquisition data for customer management, Harvard Business School, Working paper 19-091, retrieved from https://www.hbs.edu/faculty/Publication\%20Files/19-091_6268fa6e-0b57-4b01bd02-c216c2014f16.pdf on 01/25/2020.

Day, g. S (01/01/2016) Reinventing marketing in the digital era, retrieved from https://www.technologyreview.com/s/545356/reinventing-marketing-in-the-digital-era/ on 01/09/2020.

Días, j., Hamilton, d., Paquette, c. \& Sood, r. (March, 2017) How to start building your next-generation operating model, McKinsey \& Company, retrieved from https://www. mckinsey.com/business-functions/mckinsey-digital/our-insights/how-to-start-buildingyour-next-generation-operating-mode, on 02/09/2020.

Maynes, j. \& Rawson a. (March, 2016) Linking the customer experience to value, retrieved from https://www.mckinsey.com/business-functions/marketing-and-sales/our-insights/ linking-the-customer-experience-to-value on $01 / 14 / 2019$, on $01 / 20 / 2020$.

Richardson, a. (08/12/2015) Great UX doesn't guarantee a great customer experience, Harvard Business Review, Boston: USA.

Richardson, a. (11/15/2010) Using customer journey maps to improve customer experience, Harvard Business Review, Boston: USA.

Senz, k. (12/09/2019) Identifying great customers from their first purchase, Harvard Business School, retrieved from https://hbswk.hbs.edu/item/identify-great-customers-from-theirfirst-purchase j $=1046507 \& \mathrm{l}=7262 \_H T M L \& s f m c \_s u b=56483648 \& u=44213830 \& j b=4$ 69\&mid $=6336743 \&$ ucid $=003 i 0000031$ AaBAAU $\&$ em $=20200120$-LeadershipInsights SMM-1/23/2020-1046507, on 01/24/2020.

Shell m. A. \& Buell, r. W. (03/26/2019) Mitigating the negative effects of customer anxiety through access to human contact, Harvard Business School, retrieved from https://hbswk. hbs.edu/item/mitigating-the-negative-effects-of-customer-anxiety-through-access-tohuman-contact, on 01/26/2020.

Silverthorne, s. (07/11/2019) Deconstructing customer experience, Harvard Business School, retrieved from https://hbswk.hbs.edu/item/deconstructing-customer-experience, on 01/25/2020.

Simons, r. (March, 2014) Choosing the right customer. The first step in a winning strategy, Harvard Business Review, Boston: USA.

Teixeira, t. S. (2019) Unlocking the customer value chain. How decoupling drives consumer disruption, Currency, New York: USA.

Wirtz, j. \& Kaufman, r. (Apr., 2016) Revolutioning customer service, Harvard Business Review, Boston: USA. 


\begin{abstract}
Under the complexity and uncertainties of actual markets, and as never before, customers are disrupting the business game from the outside, transforming the way organizations/functional areas operate, and how people think and act. Because of this, it is necessary to focus on customer' long-term value, new organizational models, changing role of the Business/Marketing Officer, out-of-the-box capabilities, and digital technologies integration, for which Customer Experience (CE) operation levels are required to be raised in many more organizations. As a consequence, a link-to-value perspective on CE operation must be instilled at company-wide, focusing on the customer model/journey and on a new mindset, needed to implement an eco-friendly business environment.

It is studied CE, customer long-term value and related matters, proposing ideas for a better implementation in firms of every industrial sector and size. The hypothesis of this work -which was corroborated- suggests that it is possible to enhance company results, performance and competitiveness raising its $\mathrm{CE}$ operation level and implementing an ecofriendly business environment.

It was used a qualitative methodology with a bibliographical, exploratory and descriptive study, and a not experimental and transversal design.
\end{abstract}

Keywords: Customer experience - user experience - performance - competitiveness.

Resumo: Sob a complexidade e as incertezas dos mercados reais, como nunca antes, os clientes estão interrompendo o jogo dos negócios de fora, transformando a maneira como as organizações, as áreas funcionais operam e como as pessoas pensam e agem. Por isso, é necessário facer o foco no valor de longo prazo do cliente, nos novos modelos organizacionais, na mudança de função do Diretor de Negócios ou Marketing, nos recursos prontos para uso e na integração de tecnologias digitais. Para isso, a Experiência do Cliente e os níveis de operação (EC) devem ser elevados em muitas mais organizações. Como conseqüência, uma perspectiva de link-to-value deve ser infundida na operação da EC em toda a empresa, enfocada no model/journey do cliente e em uma nova mentalidade necessária para implementar um ambiente de negócios ecológico.

São estudados a EC, o valor de longo prazo do cliente e questões relacionadas, propondo idéias para uma melhor implementação em empresas de todos os setores e tamanhos industriais. A hipótese corroborada deste trabalho sugere que é possível melhorar os resultados, o desempenho e a competitividade da empresa, elevando o nível de operação da EC e implementando um ambiente de negócios ecológico. Utilizou-se metodologia qualitativa, com estudo bibliográfico, exploratório e descritivo, e um design nãoexperimental e transversal.

Palavras chave: Experiência do cliente - experiência do usuário - agindo - competitividade [Las traducciones de los abstracts fueron supervisadas por el autor de cada artículo] 